\title{
COST-BENEFIT ANALYSIS AND ITS APPLICATION TO RIVER WATER QUALITY AND INFRASTRUCTURE IMPROVEMENTS
}

\author{
F.J. HITZHUSEN \\ Department of Agricultural, Environmental and Development Economics, The Ohio State University, USA.
}

\begin{abstract}
This paper draws on the author's 30+ years of experience in teaching and applying cost-benefit analysis (CBA) methods and leading a large, 9-year research program at The Ohio State University to develop estimates of the benefits and costs of various water quality, infrastructure, scenic and historic river corridor impacts and improvements as a guide to investment planning and public policy on river and related watershed restoration. The first section of the paper summarizes the major pros, cons, definitions and tenets of CBA, and develops a set of responses to the major criticisms of CBA. The second section of the paper reports methods, analysis and results from one of the river corridor case studies. The OSU research is focused on evaluation of eight case rivers in the Great Lakes region of the United States and involves a team of environmental economists, an ecological engineer and an aquatic biologist. When the various corridor benefits or values broadly conceived are expressed in a common economic metric and compared to their full economic costs, one has a basis for assessing river corridors in an investment planning, economic development, welfare economic and public policy context.

Keywords: benefit capture, benefit transfer, contingent valuation, cost-benefit analysis, hedonic pricing, infrastructure improvements, investment planning, water quality, public policy.
\end{abstract}

\section{OVERVIEW OF COST-BENEFIT ANALYSIS}

\subsection{Pros and cons}

A frequently mentioned advantage of cost-benefit analysis (CBA) is that it forces public decision makers to examine more alternatives for accomplishing a given public objective. This assumes that there are no major constraints to the development of a comprehensive, but not necessarily exhaustive preliminary choice set of projects by cost-benefit analysts. Resources for this preliminary analysis are usually limited, but more than one alternative is generally identified.

Another cited advantage of CBA is that it clarifies the assumptions and concentrates the pro and con economic efficiency arguments into a single criterion, i.e., net national economic efficiency gains or losses. Assuming no major disagreements exist on the economic efficiency analysis, this concentration can simplify decision making among economic and non-economic factors.

Another suggested advantage of CBA is that it can be used to evaluate the magnitude and incidence of private market distortions or major spillovers/externalities. The identification and pricing of external effects can in turn help identify the appropriate boundaries or accounting stance for a public investment project, i.e., where these effects become "internalized." Assigning monetary values to external effects where possible may also increase the probability of their being explicitly considered in the public decision making process.

There is also some evidence that cost-benefit analysis is relatively neutral in its ideological content, at least as it relates to various governments' views of and/or intervention in private 
markets. The recognition of full opportunity cost of resources and full willingness to pay (WTP) or sell concepts results in a rationale for shadow pricing of private market interest rates, under employed labor, overvalued foreign exchange and environmental services that are not priced or underpriced, and income distribution. This in turn provides a form of analytical mediation between the ideological extremes of "free" market and government allocation of resources.

Some of the criticisms of CBA are simply the "flip side" of this methodology's purported strengths. Other criticisms occur because of the great diversity of this analytical methodology. Thus, some criticisms are out of context or may involve "strawman" arguments. One example of the flip side criticism is the charge that CBA may not include some alternatives, which are superior to any of those in the choice set of projects analyzed. Another is the earlier discussed charge that CBA is easily manipulated by vested interests.

The primary criticism from social scientists who are not economists is that CBA is too narrow (economic efficiency) in its focus given the many dimensions to public decision making. Thus, it tends not only to define issues too narrowly but it also does so in a professional language or jargon not generally understood. Critics further argue that this causes a particular hardship for programs or projects such as education or medical care with benefits that are more difficult to measure in monetary terms.

To the so-called cornerstone of more "rational" public decision making, critics counter that CBA has not stopped the pork-barrel. In fact, some argue that lowering of the discount rate, the addition of secondary benefits and under estimation of future maintenance costs, etc. by vested interests may actually make CBA a facilitator of the port-barrel. Even where relatively disinterested third party analysts have determined projects to be non-viable from an economic efficiency standpoint, the projects may be funded for other reasons.

Randall [1] reminds us that: (1) benefits and costs cannot count for everything, but must count for something, (2) benefit cost analysis is intended to inform decisions rather than decide issues, and (3) benefit cost can be usefully viewed as a decision rule subject to constraints. In other words, one could endorse a benefit cost decision rule where no overriding moral or ecological thresholds are threatened. Examples include basic needs [2] and income distribution [3] considerations for human well-being and safe minimum standards [4] for hydrological and ecological systems. In spite of the controversies, there are basic definitions and several basic tenets of CBA for which major consensus does exist.

\subsection{Basic definitions and tenets}

Prest and Turney [5] have described CBA as a practical way of assessing the desirability of public projects where both a long and wide view are important i.e. all relevant costs and benefits over the full life of the project are considered. Others [6] have viewed CBA as the operational side of fiscal theory concerned with quantifying and evaluating public output for more "rational" public investment planning and decision making. A major subset of CBA is the valuation of non-market benefits and costs, particularly relating to natural resource projects and environmental impacts. Although consensus on the underlying theory is strong [7], many practical problems and pressures have been encountered over the history of CBA and its applications $[3,8]$.

The underlying CBA theoretical construct is a potential Pareto improvement, i.e., with hypothetical compensation, constant marginal utility of money and costless transfers at least one person can be made better off without anyone left worse off from a project, program or policy change. The compensation of losers may not actually take place (hypothetical), but it must be possible to do so and still have net economic gains from the project [7]. 
The with/without criterion and social accounting stance are also critical components of CBA. The with/without project criterion requires that a without project future scenario be developed and compared to a with project scenario to determine the incremental gains and losses from the project. This is not the same as a before/after project criterion, which may incorrectly attribute either gains or losses to the project that would have happened without the project. The social accounting stance implies a long (time) and wide (space) view of a project. This is in contrast to a private accounting stance, which is usually smaller in both time and space [9].

Gittinger and others argue for distinguishing between financial and economic analysis where financial analysis refers to net returns to private equity capital based on market or administered prices. Financial analysis also treats taxes as a cost and subsidies as a return. Interest paid to outside suppliers of money or capital is a cost while any imputed interest on equity capital is a part of the return to equity capital. By contrast, economic (or social cost-benefit) analysis is concerned with net economic returns to the whole society and is frequently based on shadow prices that adjust for market or administered price imperfections. In economic analysis, taxes and subsidies are treated as transfer payments, i.e., taxes are part of the total benefit of a project to society and subsidies are a societal cost.

The financial vs. economic distinction is important, but the complementarity of these analytical approaches is equally relevant. Basic financial analysis provides information only on the profitability of a given enterprise to individual entrepreneurs or investors and thus gives an indication of the incentive structure and potential adoption rate. Comprehensive economic or social CBA attempts to determine profitability from a societal standpoint, taking into consideration externalities (e.g., environmental costs), pricing of unemployed or underemployed factors such as labor, currency valuation, and so on. The appropriateness of an analytical alternative lying within the financial/social cost-benefit continuum depends on who is asking the question or the "accounting stance" one is taking.

A CBA may also involve shadow pricing of labor and foreign exchange to reflect true opportunity costs as well as other adjustments for price distortions from subsidies, tariffs, etc. The discount rate may also range from private opportunity cost of capital to social productivity (adjusting for externalities) to social time preference where the concern is for future generations [6]. Valuation of uncompensated externalities (+) such as residuals leading to water and air pollution and increased or decreased environmental/ecological service flows is a major subset of CBA and is the primary focus of river valuation applications in this paper.

The major methods for measuring uncompensated externalities are: (1) clean up, avoidance and replacement costs, (2) surrogate market/revealed preference approaches including travel cost and hedonic pricing, (3) stated preference/survey approaches such as contingent valuation methods (CVM) and (4) benefit transfer and capture. (For more detailed discussions, see Hitzhusen [10] and Hanley and Spash [11].)

\section{RIVER VALUATION RESEARCH AT OHIO STATE UNIVERSITY}

Rivers have the potential to play an important role in the development of an economically depressed region by providing water supply, transportation, waste assimilation, and a wide array of recreation and tourism activities. The earliest civilizations were developed along rivers for the rich farmland along their banks and easy transportation. Irrigation of farmlands and water powered industry were followed by large dams and locks for irrigation, residential and industrial water supply, recreation boating and fishing, hydroelectric power and barge transportation of products. Rivers as a source of waste disposal are increasingly in conflict with water supply, recreation and tourism and major intra and inter-country conflicts exist over the use rights to large river systems. Thus, the river corridor 
system or basin appears to be an important, but relatively underutilized focus for economic analysis and public policy.

Treatment costs, hedonic pricing, contingent valuation, benefit transfer and capture estimation, aquatic biology, and hydrodynamic-ecologic simulation models and methods have been developed by the OSU team to value river corridor impacts. Impacts include household waste, pesticides, industrial toxics, gravel mining and agricultural run-off as well as improvements such as household waste treatment, dredging of toxics, zoning, greenways, dam removals, dam and lock upgrades, bike trails, towpaths, ramps and other recreational infrastructure (see Appendix A). Some important innovations are introduced for codification of river supply and demand factors, testing for scope, context and sequence effects in CVM mail surveys, benefit transfer and capture, structured elicitation groups for assessing constructed vs. static preferences, distribution impacts and equity weighting for contaminated river segments and integration of economic, ecologic and aquatic models for assessing dam removal. A case study of one river corridor is developed in the following section to illustrate several of the foregoing valuation methods in doing a CBA.

\section{THE MUSKINGUM RIVER COST-BENEFIT ANALYSIS CASE}

The Muskingum River, which flows 75 miles through four counties in an economically depressed region of Southeastern Ohio in the Great Lakes region of US, provides an example of the roles a river can play in regional development. Although the Muskingum tributary is small relative to the Mississippi Basin of which it is a part, it illustrates many important issues of public policy. Throughout the length of the river are ten sets of locks and dams that were constructed between 1837 and 1841 to facilitate transport of products by barge. The original features of the locks have been maintained throughout the century, making them an interesting attraction for boaters and anglers as well as for tourists, even though little cargo moves through them now. This case study is focused on one river corridor and its relevant impacts and improvements including the repair of historic dams and locks, extension of an existing bike trail, improvement of household septic systems and the past establishment of municipal zoning.

The methods applied for estimating costs in this study are market-based opportunity cost concepts. Benefits are more difficult to observe in market transactions for each of the corridor improvements, so the authors used hedonic pricing and contingent valuation survey methods, benefit transfer from previous related studies and benefit capture. In all cases conservative assumptions are made to provide lower bound estimates of net benefits and to avoid overstating the economic merits of the selected corridor improvements. To easily compare benefits and costs that are occurring over time, both the benefits and costs are expressed in 1999 dollar values at a $10 \%$ discount rate which approximates a private opportunity cost of capital.

\subsection{Concepts and methods}

A well-developed method called hedonic pricing was chosen to measure the effect of corridor improvements such as zoning and septic systems on residential property values. Hedonic pricing is a method of statistically determining the amount paid for housing and community attributes as well as for environmental goods. A basic concept of the hedonic model is that the value of an asset, in this case a home, is a function of a set of characteristics; this function is known as the hedonic price function. This can be expressed as: $P=f(\mathbf{S}, \mathbf{C}, \mathbf{Q})$, where $P$ is the price or value of the house, $\mathbf{S}$ is a vector of housing characteristics, $\mathbf{C}$ is a vector of community characteristics and $\mathbf{Q}$ is a vector 
of environmental characteristics. Hedonic pricing involves decomposing property prices into their relevant components (as expressed above) to reveal the amount by which consumers value the environmental amenities and disamenities being studied. Using the hedonic function, we can estimate the change in the asset value, in this case property value, as a result of a change in any characteristic, while holding all other characteristics constant. This change is measured by the coefficient by which that characteristic is multiplied.

Zoning regulations are included in the hedonic equation developed by Ayalasomayajula [12] to represent one community characteristic. Jud [13] concluded in his study on the effects of zoning on residential values in North Carolina, "purchasers of residential housing seek a uniformity in neighborhood land use ... and are willing to pay a premium for it." An important purpose of zoning is to protect the neighborhood residents from externalities (such as decreased property value) arising from undesirable uses of land in the same area. Zoning increases the value of land in the neighborhood by preventing these uses. The purpose of zoning in any city or township is to promote the health, safety and welfare of the citizens of that region. It is considered to be an important factor in the allocation of property rights to the residents of the region. Further, zoning contributes to the tax base of the region and it is generally the case [14] that property bidders include the higher tax rate when bidding for a property with such attributes.

Another set of community characteristics is represented by the cost and quality of the school system; distance to the three urban centers (Marietta, McConnelsville and Zanesville), and a dummy variable specifying whether a property has direct river access or not. Lack of data made it difficult to include water quality in our model even though earlier work by Epp and Al-Ani [15] found that river water quality has a positive impact on nearby non-farm residential property values.

A contingent valuation survey of the general adult population of Ohio (a random sample of licensed drivers) was designed based on the standard reference by Mitchell and Carson [16]. To identify the characteristics of people who are willing to pay for the locks and dams, bike trail and/or septic program, we utilized bid functions. A bid function explains WTP as a function of various demographic and other characteristics of the respondent. Community leaders and policy makers could use this information to identify what constituency they should be targeting in legislative, referendum or fund-raising efforts.

Boyle and Bergstrom [17] define benefit transfer as "the transfer of existing estimates of nonmarket values to a new study which is different from the study for which the values were originally estimated." They refer to the area from which the values originated as the "study site" and the area to which the values will be transferred as the "policy site." Several problems are inherent in the transfer process. In particular, the commodity, site and population characteristics of the study site must closely approximate those of the policy site. However, benefit transfer plays an important role in resource economics; it provides a rough estimate of benefits for sites where primary data collection is prohibitively expensive and/or time consuming.

The benefit transfer values used for this study were derived from a 1992 meta-analysis published by Walsh et al. [18]. The authors reviewed 120 outdoor recreation studies from sites in the U.S. between 1968 and 1988. They estimated benefits resulting from various recreational activities including camping, fishing, boating, hunting, picnicking, swimming and sightseeing. In their paper, Walsh et al. gave the activities and their median values per recreator day in 1987 dollars. The values from Walsh et al.'s study were appreciated to 1999 dollars using a consumer price index.

For this study, we deflated the day use values to reflect the median household income for the three county areas, which is lower than that of American households that are more relevant to the Walsh study. Because the proportion of motorized to non-motorized boating on the river was unknown, the 
average of the two values was used to calculate the benefits. On average, lock visitors probably do not spend more than an hour at a site and it is unknown whether or not they stop at more than one lock, or other river businesses. Therefore, a conservative assumption was made and the value of visitation supplied by the Walsh study based on an 8-hour day was divided by eight for use in this study. This resulted in an average day use value of $\$ 3.11$ to be multiplied times the average annual visitation to the locks.

In environmental economics benefit capture generally relates to attempts by environmental economists to estimate non- or extra-market values for various natural resource projects or policy initiatives. Pearce and Turner [19] and others have suggested that environmental economics is concerned with not just the measurement or estimation but also the capture and internalization of benefits and costs from environmental service and residual flows. Considerable research activity over the past 20 years or more has been concerned with non-market valuation techniques for measuring and transferring the economic benefits including non-use values of various environmental goods and services [17, 18, 20]. Less attention has been given to how some of these benefits could be captured and by whom in a real world policy context. This paper explores two approaches (hedonic price links to tax revenues and CVM bid functions) for answering these questions in the context of a benefit cost analysis of several proposed upgrades to the Muskingum River corridor in SE Ohio. (See Hitzhusen et al. [21] for a more detailed discussion of data collection and analysis and Hitzhusen et al. [22] for conceptual clarification of benefit capture.)

\subsection{Results of analysis}

\subsubsection{Infrastructure results}

Earlier, the US Army Corps of Engineers analysis projected large increases in Muskingum River corridor recreation and maintained that these values justified large future investments in lock and dam improvements. The analysis by Hitzhusen $e t$ al. [21] shows that recreational use values do not offset the costs of lock and dam repair/upgrades. This is demonstrated with evidence that repairs and upgrades made in recent years have not resulted in any measurable increases in recreation use. Decreases in lock use have in fact been the norm. This evidence was combined with benefit transfer techniques and day use values for various types of recreation (e.g., boating, fishing, picnicking and visiting) common in the Muskingum Corridor.

Since use values are inadequate, non-use (existence, historic preservation) values were explored by implementing a contingent valuation survey of WTP for lock and dam repair by a sample of the adult residents of Ohio. These results suggest benefits large enough to exceed the discounted present value costs of repairing, maintaining and operating the locks and dams; the benefit cost ratio is 1.51 and the net present value (NPV) is $\$ 5,876,000$.

The proposed extension of the Zane's landing bike trail was evaluated with a similar approach. Construction cost estimates were available for the proposed trail and it was possible to get information on annual operating and maintenance costs from other trails in Ohio. The benefits were estimated by aggregating the results from the aforementioned contingent valuation survey and the forecasted trail use (see Appendix B). Once again, the findings are supportive; the benefit cost ratio is 6.49 and the NPV is $\$ 11,261,000$.

\subsubsection{Zoning and septic system results}

The costs of zoning and improved household septic systems were determined from interviewing those involved in the provision of each. The analysis of the benefits was more complex. Both 
zoning and household septic systems are expected to impact residential property values, so the hedonic pricing model discussed earlier was utilized to estimate this effect. In the case of household septic systems, it was presumed appropriate to assess benefits accruing to other stream users besides river corridor residents. Thus, the contingent valuation survey of Ohio adult population was utilized to approximate these values (see Appendix B) and the results were combined with the hedonic estimates.

From the hedonic model, it was possible to determine the effect of the presence of zoning, central sewer system, individual household septic system and river proximity on residential property values in the corridor. The aggregate values are as follows: zoning $\$ 912,000$; central sewer $\$ 678,000$; household septic systems $\$ 1,470,000$; and river proximity $\$ 637,000$. The hedonic benefits for zoning when compared with costs show a benefit cost ratio of 5.39 and NPV of $\$ 630,000$. The combined hedonic and CVM results for household septic systems (with a local government $50 \%$ cost share of installation and full coverage of repair and cleaning) showed a benefit cost ratio of 1.44 and NPV of $\$ 8,274,812$. The results of a program of full subsidization were not as economically viable; the benefit cost ratio was 0.72 and NPV $-\$ 2,590,000$.

At a 10\% discount rate (a discount rate commonly used in this type of analysis) it is instructive to compare and aggregate the net present value and benefit cost ratio results for the corridor improvements. Table 1 presents these results. The NPV and B/C formulas used to calculate the values in Table 1 are as follows:

$$
\mathrm{NPV}=\sum_{t=1}^{T} \frac{\left(B_{t}-O_{t}\right)}{(1+i)^{t}}+K, \quad B / C=\sum_{t=1}^{T} \frac{\left(B_{t} /(1+i)^{t}\right)}{\left(O_{t} /(1+i)^{t}\right)+K},
$$

where $B_{t}$ is the benefit in year $t, O_{t}$ is the operating cost in year $t, K$ is the initial capital outlay, $i$ is the discount rate and $T$ is the time horizon.

When using the benefit cost ratio efficiency criterion, the bike trail extension and zoning rank first and second respectively followed by lock and dam operation and repairs and upgraded household septic systems. With the net present value criterion, which is influenced by the scale or size of investments, the bike trail ranks first, followed by the locks and dams, the upgraded household septic systems and zoning respectively. In total, the four improvements have a net present value of $\$ 19.8$ million and a $\mathrm{B} / \mathrm{C}$ ratio of 2.07 .

\subsubsection{Benefit capture results}

Regarding benefit capture, the hedonic pricing model linked to tax revenue functions showed increases in tax revenue from zoning accruing to the cities of Zanesville and Marietta (see Table 2)

Table 1: Summary of aggregate benefit cost results in 1999 dollars, $i=10 \%$.

\begin{tabular}{lrrrc}
\hline & $\begin{array}{c}\text { Present value of } \\
\text { benefits }(\$)\end{array}$ & $\begin{array}{c}\text { Present value of } \\
\text { costs }(\$)\end{array}$ & \multicolumn{1}{c}{$\begin{array}{c}\text { Net present } \\
\text { value }(\$)\end{array}$} & Benefits/costs \\
\hline Zoning & 774,000 & 144,000 & 630,000 & 5.39 \\
Septic (cost-sharing) & $6,692,000$ & $4,641,000$ & $2,051,000$ & 1.44 \\
Bike trail & $13,311,000$ & $2,050,000$ & $11,261,000$ & 6.49 \\
Lock and dam & $17,511,000$ & $11,635,000$ & $5,876,000$ & 1.51 \\
Total & $38,290,000$ & $18,470,000$ & $19,816,000$ & 2.07 \\
\hline
\end{tabular}


Table 2: Estimated annual property tax revenue increases from corridor improvements.

\begin{tabular}{lcccr}
\hline City & Tax millage (\$) & $\begin{array}{c}\text { Coefficient } \\
\text { estimate }\end{array}$ & $\begin{array}{c}\text { Number of houses } \\
\text { in the area }\end{array}$ & $\begin{array}{r}\text { Tax revenue } \\
\text { increase }(\$)\end{array}$ \\
\hline Zoning & & & & \\
Zanesville & 44.22 & 269 & 485 & 5782.21 \\
Marietta & 43.18 & 269 & 464 & 5389.55 \\
Total & & & 949 & 11171.76 \\
Septic system & 44.22 & 67 & 1002 & 2975.38 \\
Muskingum & 43.18 & 67 & 726 & 2100.36 \\
Washington & & & 1728 & 5075.74 \\
Total & & & & \\
\hline
\end{tabular}

Table 3: Estimated annual school district tax revenues generated by zoning and septic system.

\begin{tabular}{lcccc}
\hline City & Tax millage (\$) & $\begin{array}{c}\text { Coefficient } \\
\text { estimate }\end{array}$ & $\begin{array}{c}\text { Number of houses } \\
\text { in the area }\end{array}$ & $\begin{array}{c}\text { Increase in } \\
\text { tax revenue }(\$)\end{array}$ \\
\hline $\begin{array}{l}\text { Zoning } \\
\text { Muskingum }\end{array}$ & 24.61 & 269 & 1487 & 9844.07 \\
Washington & 26.23 & 269 & 1190 & 8396.49 \\
Total & & & 2677 & 18240.56 \\
Septic system & 24.61 & 67 & 1002 & 1652.60 \\
Muskingum & 26.23 & 67 & 726 & 1275.70 \\
Washington & & & 1728 & 2928.30 \\
Total & & & &
\end{tabular}

to be about two times larger than the increases from improved household rural septic systems in Muskingum and Washington counties. The hedonic based tax revenue functions for school districts in Muskingum and Washington counties (see Table 3) showed six fold differences between zoning and improved septic system impacts. However, the annual revenue increases from zoning and household septic system improvements are generally larger to the school districts than to the local governments.

The aggregate evidence on WTP from the CVM survey resulted in benefit cost ratios of 1.4-6.5 for the four river corridor improvements (see Table 1). This in turn prompted two river advocacy groups, Rivers Unlimited and Community 20/20, to work with US Senator DeWine in developing a $\$ 3.4$ million appropriation request which was moving through the appropriation process until the disruption of the " $9 / 11$ " event. The CVM instrument was not originally designed with binary bid function estimation in mind (see Appendix B), but it was possible to specify a binary dependent variable and get the Probit estimates presented in Table 4. Despite the bid function limitations, some general conclusions can be drawn regarding what groups of people are more likely to have positive WTP for these improvements. 
Table 4: Bid functions from CVM Ohio survey (Probit).

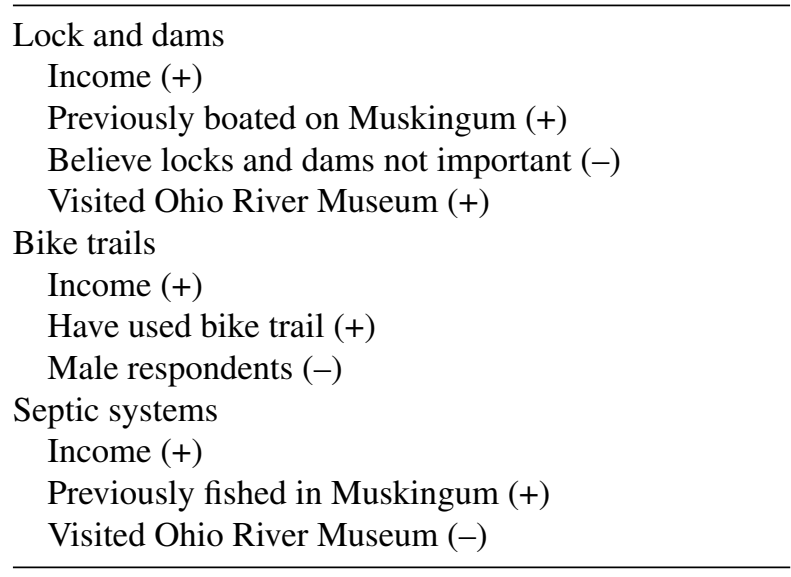

The CVM bid function results show that previous boaters on the Muskingum River and Museum visitors are likely to have higher WTP for the locks. These two groups can be easily solicited using address lists of museum visitors and lock users. Museum visitors are, however, less likely than nonmuseum visitors to have positive WTP for the bike trail or the septic program. This would suggest that the museum visitors should only be solicited for the locks and not for bike trail or the septic program. Users of bike trails that are adjacent to rivers other than the Muskingum are more likely to have positive WTP for both the bike trail and the septic program; this group of people could be targeted for both programs. (See Hitzhusen et al. [21] for more details.)

\section{CONCLUSIONS AND IMPLICATIONS}

As stated earlier, CBA is a very useful methodology for informing decision making on resource allocation regarding important public policy issues. It cannot measure and quantify everything that may be of concern in the public policy process, particularly moral, hydrological and ecological thresholds or constraints. However, it is possible to view CBA as a way to maximize economic wellbeing, subject to these constraints. Examples of suggestions for more effective CBA in informing the political decision making process include:

1. More attention devoted to estimating technological externalities, identifying critical thresholds and safe standards and specifying the appropriate accounting stance.

2. More frequent and systematic ex post $\mathrm{CBA}$ to compare to ex ante CBA to reduce uncertainty and errors in ex ante estimation.

3. More concerted efforts to keep responsibility for CBA within relatively disinterested or neutral individuals and institutions.

4. More rigorous development of methods for benefit transfer and capture.

5. More detailed analysis of the distribution of costs and benefits by income class, region, ethnicity, etc.

The case study in this paper as a subset of the long term research program at OSU on valuation of water quality and infrastructure improvements of river systems highlights the role CBA can play. These research results have some important policy implications in spite of the limitations 
highlighted and the need for further research. First, the methods and results demonstrate that it is possible to develop economic metrics for the costs and benefits of selected river corridor attributes and improvements. In addition, these results provide evidence for ranking corridor improvements based on the benefit cost ratio and net present value of each attribute. However, if the magnitude or scale of the attribute improvements varies considerably, the ranking of attributes according to benefit cost ratio and net present value may be different.

Benefit cost ratios greater than one and positive net present values were evident at the $10 \%$ discount rate for all Muskingum River Corridor attributes and improvements except for fully subsidized household septic systems. So, in general, the economic rationale for river water quality and infrastructure improvement is supported. As an investment strategy, one might propose to proceed by implementing corridor improvements on the basis of their relative economic efficiency based on their benefit cost ratios. Some caution must be exercised. One might expect improved septic systems, lock and dam restoration and the bike trail extension to result in increased economic well-being in the Muskingum River Corridor. However, limited opportunity may exist for additional municipal zoning and hence it is less likely that additional benefits from zoning will occur in the near future.

There are some benefit capture implications from the hedonic-tax revenue and bid function results. The absolute numbers, e.g., annual property tax revenue increases from zoning in the small cities of $\$ 11,172$ and from improved household septic systems in two rural counties of $\$ 5076$ may not seem large, but at the margin, these may not be trivial increases to small municipal and rural county governments. The annual increases in school district tax revenues in Muskingum and Washington counties from zoning and improved household septic systems totaled $\$ 21,169$. Explanatory evidence from the CVM bid functions can be used to target fund raising from individual citizen-consumers as indicated, but this evidence could also be strengthened and combined with the CVM aggregate WTP evidence to develop a political economy approach and generate majority support for legislative and referendum efforts. This would seem to be a promising area for future research to assist initiatives for restoration and/or protection of rivers and other natural resource systems.

One potential advantage of these economic methods and results is to reduce conflict and transaction costs in the policy process. For example, applying a common economic metrisc to river corridors and other natural systems may make it possible for state and federal departments of natural resources and economic development to find more common ground in improving the well being for citizen-consumers. Business and environmental interest groups may also be able to build more consensus and lower decision-making (e.g., litigation) costs. Economic analysis of a river corridor or basin as a hydrologic unit may also facilitate cooperation across political boundaries for more optimal public policy and management of this natural resource system. Further analysis of selected river systems in the Great Lakes region of the US has culminated in a book from Edward Elgar [10], which is targeted at audiences in North America and Europe concerned with economic valuation of river systems. 


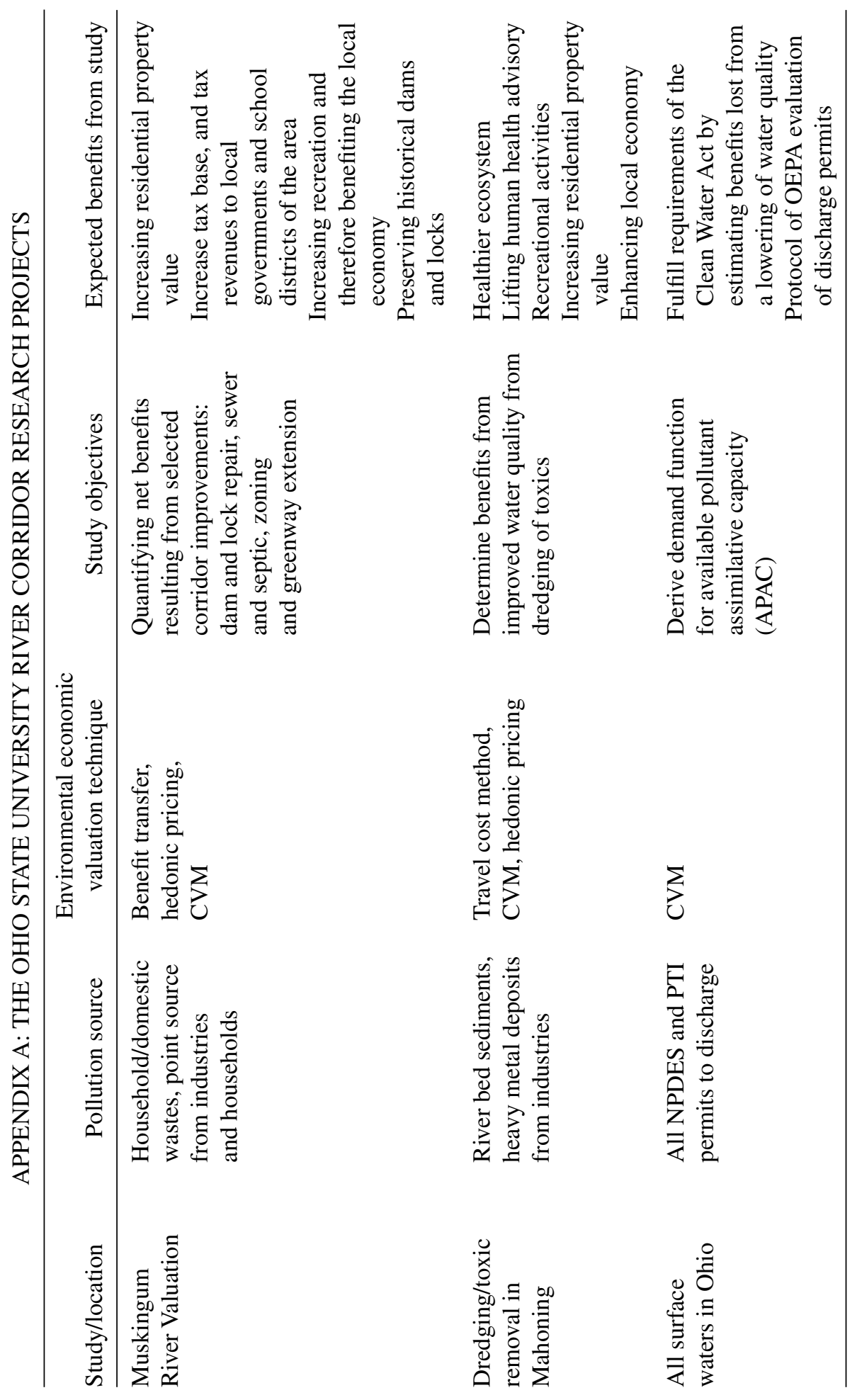




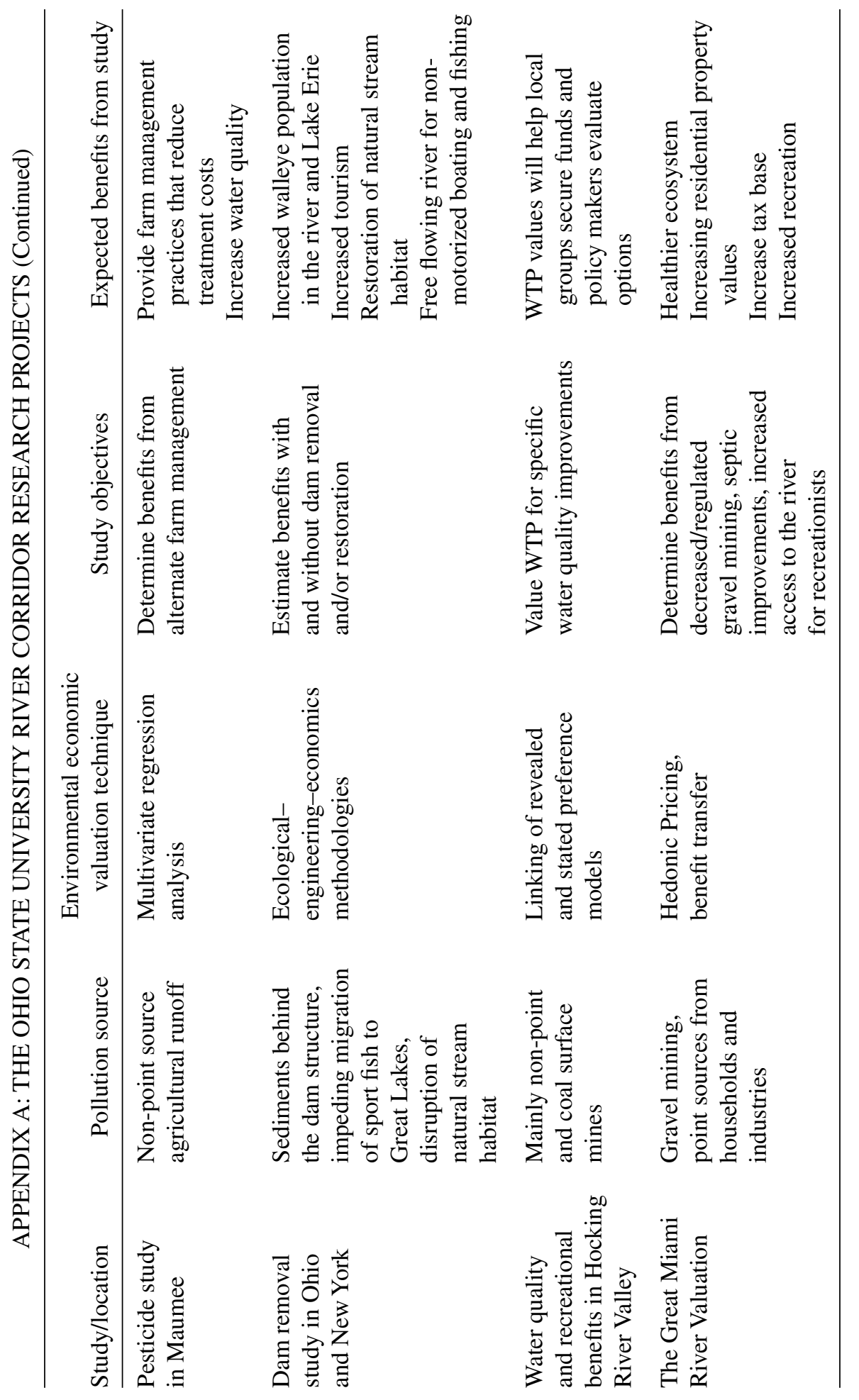




\section{APPENDIX B: CONTINGENT VALUATION METHODS SURVEY}

There is currently a short bike path (2.7 miles long) located in northern Zanesville. An extension of this path has been proposed that will run north to Dresden. Imagine you are approached by someone who asks you to donate towards the extension of the Zanesville trail. How much would you pay (as a one time donation) towards funding the extension of the Zanesville bike trail along the Muskingum River?

$\$ 0.00$
$\$ 10.00$
$\$ 25.00$
$\$ 50.00$
$\$ 75.00$
$\$ 100.00$
More than $\$ 100.00$ (please specify amount)

The effectiveness and existence of household waste treatment systems varies across households in the Muskingum River. That is, some households have septic systems that are in good working order, others have septic systems that are not functioning well and still others do not have septic systems and are not connected to a sewage treatment plant. Because household waste is emptied directly into the river after it has or has not been treated, it is regarded as a threat to the water quality of the Muskingum River.

Imagine you were asked to contribute towards an effort to improve the treatment of household waste produced by homes that are located on the banks of the Muskingum River. This effort would involve installation of treatment plants in areas where doing so is economically feasible (due to large enough household density). In areas where individual septic systems are necessary, the local health departments would service (replace baffles, repair motors, etc.) and pump out every household's septic system at no cost to the owner. How much would you pay (as a one time donation) to help install, upgrade and maintain household septic and sewage treatment along the Muskingum River?

$$
\begin{aligned}
& \$ 0.00 \\
& \$ 10.00 \\
& \$ 25.00 \\
& \$ 50.00 \\
& \$ 75.00 \\
& \$ 100.00
\end{aligned}
$$

More than $\$ 100.00$ (please specify amount)

\section{REFERENCES}

[1] Randall, A., Why benefits and costs matter. Choices, 2nd Quarter, pp. 38-41, 1999.

[2] Hicks, N., Is there a tradeoff between growth and basic needs? Finance and Development, 17(2), pp. 17-20, 1980.

[3] Hitzhusen, F.J., Benefit cost analysis reader, AEDE 631, The Ohio State University: Columbus, OH, USA, 2006.

[4] Vaughn, G.F., Siegfried Von Ciriacy Wantrup and his safe minimum standard of conservation. Choices, 4th Quarter, pp. 30-33, 1997.

[5] Prest, A. \& Turney, R., Cost-benefit analysis: a survey. Economic Journal, 75(300), pp. 683-735, 1965. 
[6] Burkhead, J. \& Jerry, M., Public Expenditure, Aldine, Atherton, Inc.: Chicago, 1971.

[7] Dasgupta, A.K. \& Pearce, D.W., Cost-Benefit Analysis, Theory and Practice, The MacMillan Press Ltd.: London, 1978.

[8] Hitzhusen, F.J., Cost-benefit analysis: cornerstone or Achilles' heel of social science? ESO 1230, AERS Department, The Ohio State University, Columbus, OH, 1984.

[9] Gittinger, J.P., Economic Analysis of Agricultural Projects, John Hopkins University Press: Baltimore, MD, 1982.

[10] Hitzhusen, F.J. (ed.), Economic Valuation of River Systems, Edward Elgar Publishing: Northampton, MA, 2007.

[11] Hanley, N. \& Spash, C.L., Cost Benefit Analysis and the Environment, Edward Elgar Publishing: Brookfield, VT, 1995.

[12] Ayalasomayajula, R., Economic Valuation of River Corridor Attributes: A Hedonic and NIE Approach, Unpublished Master's Thesis, The Ohio State University, Columbus, OH, USA, 2000.

[13] Jud, D.G., Effects of zoning on single-family residential property values: Charlotte, North Carolina. Land Economics, 56(2), pp. 142-153, 1980.

[14] Hite, D., Welfare Measures for an Environmental Disamenity in the Residential Real Estate Market, Unpublished PhD Dissertation, The Ohio State University, Columbus, $\mathrm{OH}$, USA, 1995.

[15] Epp, D.J. \& Al-Ani, K.S., The effect of water quality on rural nonfarm residential property values. American Journal of Agricultural Economics, 61(3), pp. 529-534, 1979.

[16] Mitchell, R.C. \& Carson, R.T. Using Surveys to Value Public Goods: The Contingent Valuation Method, Resources for the Future: Washington, DC, 1989.

[17] Boyle, K.J. \& Bergstrom, J.C., Benefit transfer studies: myths, pragmatism and idealism. Water Resources Research, 28, pp. 657-663, 1992.

[18] Walsh, R.G., Johnson, D.M. \& McKean, J.R., Benefit transfer of outdoor recreation demand studies, 1968-88. Water Resources Research, 28, pp. 707-713, 1992.

[19] Pearce, D.W. \& Turner, R.K., Economics of Natural Resources and the Environment, Harvester Wheatsheaf: Hemel Hempstead, Hertfordshire, UK, 1990.

[20] French, D.D. \& Hitzhusen, F.J., Status of benefits transfer in the United States and Canada: a comment. Canadian Journal of Agriculture and Economics, 49(2), pp. 259-261, 2001.

[21] Hitzhusen, F.J., Lowder, S. \& Ayalasomayajula, R., Muskingum River economic valuation, AED Economics Department, The Ohio State University, Columbus, OH, Summer 2000.

[22] Hitzhusen, F.J., Ayalasomayajula, R. \& Lowder, S., Some conceptual clarification and empirical evidence on benefit capture: a river corridor case, AEDE Working Paper, The Ohio State University, Columbus, OH, September 2002.

This paper is an extended version of the one presented by the authors at the 1st International Conference on Environmental Economics and Investment Assessment, held on the island of Mykonos in 2006, Volume 98, WIT Transactions on Ecology and the Environment (ISBN: 1-84564-046-2/Online ISSN: 1743-3541). Edited by K. Aravossis, C.A. Brebbia, E. Kakaras and A.G. Kungolos. 